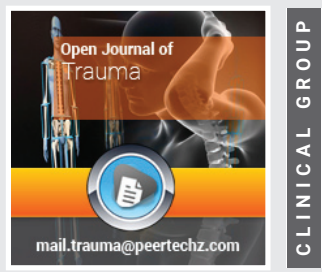

\title{
Insects involved in
}

\section{decomposing corpses in the Constantine region-Algeria}

\author{
Benkenana Naima* \\ Laboratoire de Biosystématique et Ecologie des Arthropodes, Université Mentouri, Constantine, route \\ d’Aïn-El-Bey, 25000, Constantine, Algérie
}

Received: 06 April, 2020

Accepted: 27 May, 2020

Published: 28 May, 2020

*Corresponding author: Benkenana Naima, Laboratoire de Biosystématique et Ecologie des Arthropodes, Université Mentouri, Constantine, route d'Aïn-El-Bey, 25000, Constantine, Algérie,

E-mail: benkenanan@yahoo.co.nz

Keywords: Decomposition; Body; Insects; Diptera; Coleoptera

https://www.peertechz.com

Check for updates

\begin{abstract}
Forensic entomology is based on the use of scavenging insects to estimate the time of death in the course of judicial inquiries and allows in some cases specify the circumstances of death. This technique is based on solid scientific basis and is now commonly used as part of criminal cases.

This process involves the chemical and physical breakdown of tissue by microorganisms such as fungi and bacteria.

The decomposition of animal body, it is known that there are five stages; fresh corpse, rot, fermentation, dehydration and skeleton. Tracking all stages of decomposition of dog body in the period from 15 February to 26 April 2018. With the collection of 1135 insects (whole individuals and larvae) over the animal's corpse and around it, 21 insects belonging to three orders were identified: Diptera, Coleoptera and Hymenoptera.
\end{abstract}

The results of this study add data to forensic entomology in Algeria and its potential for use in judicial investigations.

\section{Introduction}

Forensic entomology comprises three main disciplines, which are: urban entomology, the entomology of stored foodstuffs and criminal entomology which we are interested in. When an animal species dies, it will be quickly visited and colonized by many invertebrates. The majority of which will be insects and it is first necessary to make a clear distinction between the different functional groups which can be found on a corpse [1]. So, forensic entomology is concerned with the application of the study of insects and other arthropods, which have an important role in the service of justice [2].

Constantine region located in eastern Algeria and characterized by a semiarid climate with cold winter. Our study aims to identify the types of insects that contribute to the analysis of corpses (the body of an animal) according to climatic conditions of the study area.

\section{Material and methods}

The presence and activity of insects also influence the process of decomposition as different types of organisms are attracted at each stage of decomposition. In our current study, we followed the decomposition of dog corpse (15-kilogram). It was obeserved near the Biosystematic and ecology of Arthropods laboratory at the Mentouri Constantine University $\left(36^{\circ} 20^{\prime} 16.20^{\prime \prime} \mathrm{N} ; 6^{\circ} 37^{\prime} 33.32^{\prime \prime} \mathrm{E}, 571 \mathrm{~m}\right.$ altitude), on the day of 15 february. After, the corpse was put in a cage to protect it from predators. The study period lasted approximately three months, from 15 February to 26 April, 2018.

Samples were taken at an hourly rate daily to the laboratory, every two hours from 8 a.m. until 5 p.m. It were taken from the various traps installed in the cage (barber and yellow traps) and also direct captures from the corpse. In the laboratory, insects were sorted and classified using classification keys $[3,4]$, magnifying lenses and various tools used in the study of insects Table 1.

\section{Results}

The speed with which a body passes in each of these steps depends on several factors such as climate, body size and 
Table1: List of species of insects that visited the corpse.

\begin{tabular}{|c|c|c|}
\hline Order & Family & Species \\
\hline \multirow{6}{*}{ Diptera } & \multirow{2}{*}{ Calliphoridae } & Calliphora vicina (Robineau Desvoidy, 1830) \\
\hline & & Lucilia sericata (Meigen, 1826) \\
\hline & Anthomyiidae & Anthomyia pluvialis (Linnaeus, 1758) \\
\hline & Muscidae & Musca domestica (Linnaeus, 1758) \\
\hline & Fanniidae & Fannia sp \\
\hline & Piophilidae & $s p$ \\
\hline \multirow{14}{*}{ Coleoptera } & \multirow{2}{*}{ Silphidae } & Thanatophilus rugosus (Linnaeus, 1758) \\
\hline & & Necrodes littoralis (Linnaeus, 1758) \\
\hline & \multirow{3}{*}{ Staphylinidae } & Creophilus maxillosus (Linnaeus, 1758) \\
\hline & & Ontholestes sp \\
\hline & & Philonthus sp \\
\hline & \multirow{3}{*}{ Histeridae } & Saprinus semistriatus (Scriba, 1790) \\
\hline & & Margarinotus brunneus (Fabricius, 1775) \\
\hline & & Margarinotus ventralis (Marseul, 1854) \\
\hline & Dermestidae & Dermestes frischii (Kugelann, 1792) \\
\hline & \multirow{2}{*}{ Trogidae } & Trox sabulosus (Linnaeus, 1758) \\
\hline & & Trox scaber (Linnaeus, 1767) \\
\hline & Cleridae & Necrobia rufipes (De Geer, 1775) \\
\hline & Scarabaeidae & $s p$ \\
\hline & Nitidulidae & Omosita colon (Linnaeus, 1758) \\
\hline Hymenoptera & Pteromalidae & Nasonia $s p$ \\
\hline Total : 3 & 14 & 21 \\
\hline
\end{tabular}

weight, and whether it has been moved or buried. By tracking all stages of decomposition of the body (dog) in the period from 15 February to 26 April 2018. With the collection of 1135 insects (whole individuals and larvae) over the animal's corpse and around it, 21 insects belonging to three [3], ranks were identified: Diptera, Coleoptera and Hymenoptera. The Calliphoridae family is the most represented in the order of Diptera, followed by Anthomyiidae, Muscidae, Sarcophagidae, Fanniidae, and Piophilidae. As for the Coleoptera rank, the most representative families are Dermestidae and-Nitidulidae.

The results after 24 hours indicate that the species of the family Caliphoridae are the first visitors including the two species; Lucilia sericata and Chrysomya albeceps.

\section{Discussion and conclusion}

Entomology is one of the ancient sciences in Algeria (Lucas, Brisout 1849), but the focus has been on agricultural and medicinal insects. Several national laboratories and institutes are currently interested in this. As for forensic forensics recently received attention, the first national laboratory in this field was opened in 2008. He followed the National Gendarmerie and started his actual activities in 2011. The number of files he received reached 190 in 2016 [5].

Forensic medical entomology is concerned with studying insects related to a human body and one of its most important applications is to determine the time that has passed since death. As for forensic entomology, it is concerned with the study of throwing flies, the first carcasses of the carcass , which varies according to the surrounding milieu and season of the year [6] and the ability to incubate and breed in the laboratory [7].

In our current study, 21 species were identified, with the first arriving species being from the Diptera order, followed by the Coleoptera rank, and in the latter the species belonging to the Hymenoptera rank. The results of this study are consistent with the findings of many researchers [8-10].

According to the study of Bouleknefet in the Skikda region in 2015 and 2016 [11,12], two species that were not registered in our current study were identified, namely Phormia regina and Lucilia illustis due to the conditions of each region. Skikda is a region with a humid climate, and the Constantine region under study is semi -dry climate.

The study confirms the importance of using forensic forensics in investigations and recommends that such studies be circulated to all regions of the country, and to establish a database of the species present in each region to facilitate judicial investigations using forensic entomology. And it will stress the importance of detailed analysis of the phenomenon of decomposition and climatic conditions, whether short or long-term when estimating the time of death.

This work gave us an idea of the diversity of the scavenging entomofauna in the Constantine region. Our study remains incomplete and needs to be deepened research remains necessary to identify and study the biological cycles of the main species and the effects of climatic factors on the distribution of these insects.

\section{References}

1. Wyss C, Cherix D (2006) Traité d'entomologie forensique. Presses Polytechniques et Universitaires Romandes, Lausanne 317. Link: https://bit.ly/3gswcZj

2. Hall RD (2001) Introduction: perceptions and status of forensic entomology.

3. Entomology (2009) The Utility of Arthropods in Legal Investigations. J. H. Byrd and J. L. Castner, Eds., 115, CRC Press, Boca Raton, Fla, USA

4. Szpila K, Hall MJR, Pape T, Grzywacz A (2012) Morphology and identification of first instars of the European and Mediterranean blowflies of forensic importance. Part II. Luciliinae. Link: https://bit.ly/2ZKtNTO

5. Bajerlein D, Kounwerski S, Madra A (2012) $9^{\text {th }}$ Meeting of the European Association for Forensic entomology, Torun, Poland.

6. Toumi M (2017) The first National Meeting of Forensic Entomology, National Institute of Criminalistics and Criminology (NICC/CG) Bouchaoui (Algiers).

7. Wells JD, Greenberg B (1994) Effect of the red imported fire ant (Hymenoptera: Formicidae) and carcass type on the daily occurrence of postfeeding carrionfly larvae (Diptera: Calliphoridae, Sarcophagidae). J Med Entomol 31: 171-174. Link: https://bit.ly/36AoEiN

8. Byrd JH, Castner JL (2010) Insects of forensic importance. In Forensic entomology: the utility of using arthropods in legal investigations (ed. by J.H. Castner \& J.L. Byrd) CRC Boca Second Edition, Raton, FL 29-126.

9. Benmira S (2010) Contribution à l'étude systématique des insectes nécrophages d'intérêt médico-légal, Mémoire de Master Université de Constantine, 39.

10. Benmira S (2018) Etude systématique de la faune nécrophage d'intérêt médico-légale sur cadavre animal et activité saisonnale des diptères Calliphoridae. Stade de décomposition. Thèse de doctorat, Université des Frères Mentouri Constantine Faculté des sciences de la nature et de la vie Département de Biologie Animale 3: 50-51. Link: https://bit.ly/2zFWbfl 
11. Charabidze D (2008) Etude de la biologie des insectes nécrophages et application à l'expertise en entomologie médico-légale. Thèse Doctorat, Université de Lille, 205.

12. Bouleknefet $F$, Berchi S, Lambiase S (2015) Preliminary study of necrophagous Diptera succession on a dog carrion in Skikda, North-east of Algeria. J Entomol Zool Stud 3: 364-369. Link: https://bit.ly/2AeviiA
13. Bouleknefet $F$ (2016) Caractérisation des insectes nécrophages, leur utilité en médecine légale et dans les enquêtes judiciaires. Thèse de doctorat, Université des Frères Mentouri Constantine Faculté des sciences de la nature et de la vie Département de Biologie Animale 1-144. Link: https://bit.ly/2XD9MMd
Discover a bigger Impact and Visibility of your article publication with Peertechz Publications

\section{Highlights}

- Signatory publisher of ORCID

* Signatory Publisher of DORA (San Francisco Declaration on Research Assessment)

- Articles archived in worlds' renowned service providers such as Portico, CNKI, AGRIS, TDNet, Base (Bielefeld University Library), CrossRef, Scilit, J-Gate etc.

* Journals indexed in ICMJE, SHERPA/ROMEO, Google Scholar etc.

* OAI-PMH (Open Archives Initiative Protocol for Metadata Harvesting)

* Dedicated Editorial Board for every journal

* Accurate and rapid peer-review process

* Increased citations of published articles through promotions

* Reduced timeline for article publication

Submit your articles and experience a new surge in publication services (https://www.peertechz.com/submission).

Peertechz journals wishes everlasting success in your every endeavours.

Copyright: (c) 2020 Naima B. This is an open-access article distributed under the terms of the Creative Commons Attribution License, which permits unrestricted use distribution, and reproduction in any medium, provided the original author and source are credited. 